\title{
ACRITARCHS FROM THE CAMBRIAN-ORDOVICIAN BOUNDARY BEDS AT TÕNISMÄGI, TALLINN, NORTH ESTONIA
}

\author{
Ivo PAALITS
}

Technische Universität Berlin, Institut für Geologie und Paläontologie (Institute of Geology and Paleontology, Technical University of Berlin), ACK 14, Ackerstraße 71-76, Berlin 13355, Deutschland (Germany)

Presented by D. Kaljo

Received 3 August 1994, accepted 20 October 1994

Abstract. The general distribution of palynomorphs through the Cambrian-Ordovician boundary interval at Tõnismägi allows to establish five acritarch assemblages corresponding to the $P$. spinolosa, Cordylodus proavus, C. intermedius, C. lindstromi, and C. angulatus-C. rotundatus zones. Two new species are described (?Cymatiogalea procuvillieri sp. n. and Stelliferidium cortinulamorphum sp. n.).

Key words: acritarch, biostratigraphy, Upper Cambrian, Tremadoc, Estonia.

\section{INTRODUCTION}

Several faunal groups have been studied from the Tõnismägi outcrop to define the Cambrian-Ordovician boundary in the Baltic region (Kaljo et al., 1988). Unfortunately, the Upper Cambrian and Tremadoc sequence, characterized by shallow water terrigeneous rocks in the Baltic-Ladoga klint area and an incomplete discontinuous succession with numerous disconformities, does not suit as key section for a boundary. Previous information on the lithology, sedimentology, and fossil records from Tõnismägi is given in Kaljo et al. (1988). The present paper adds some more information on the distribution of the acritarchs in the same section. The 19 samples studied were collected from two profiles located about $50 \mathrm{~m}$ from each other (see Fig. 1). Most of them, excluding those from the Tiskre Formation (Lower Cambrian), contain acritarchs, of medium to good preservation.

Three different levels (Cordylodus proavus, C. intermedius, or C. lindstromi) have been proposed to be discussed by the International Working Group on the Cambrian-Ordovician Boundary. However, no final decision has been made yet. For this reason the lower boundary of the Tremadoc remains open in this paper.

\section{DISTRIBUTION OF ACRITARCHS}

The acritarchs identified from the Tonnismägi section are listed in Fig. 2. Some selected acritarchs are illustrated on PIs. I-III. Their general distribution through the study interval allows of the establishment of five acritarch assemblages, which are numbered formally as A1-A5. 


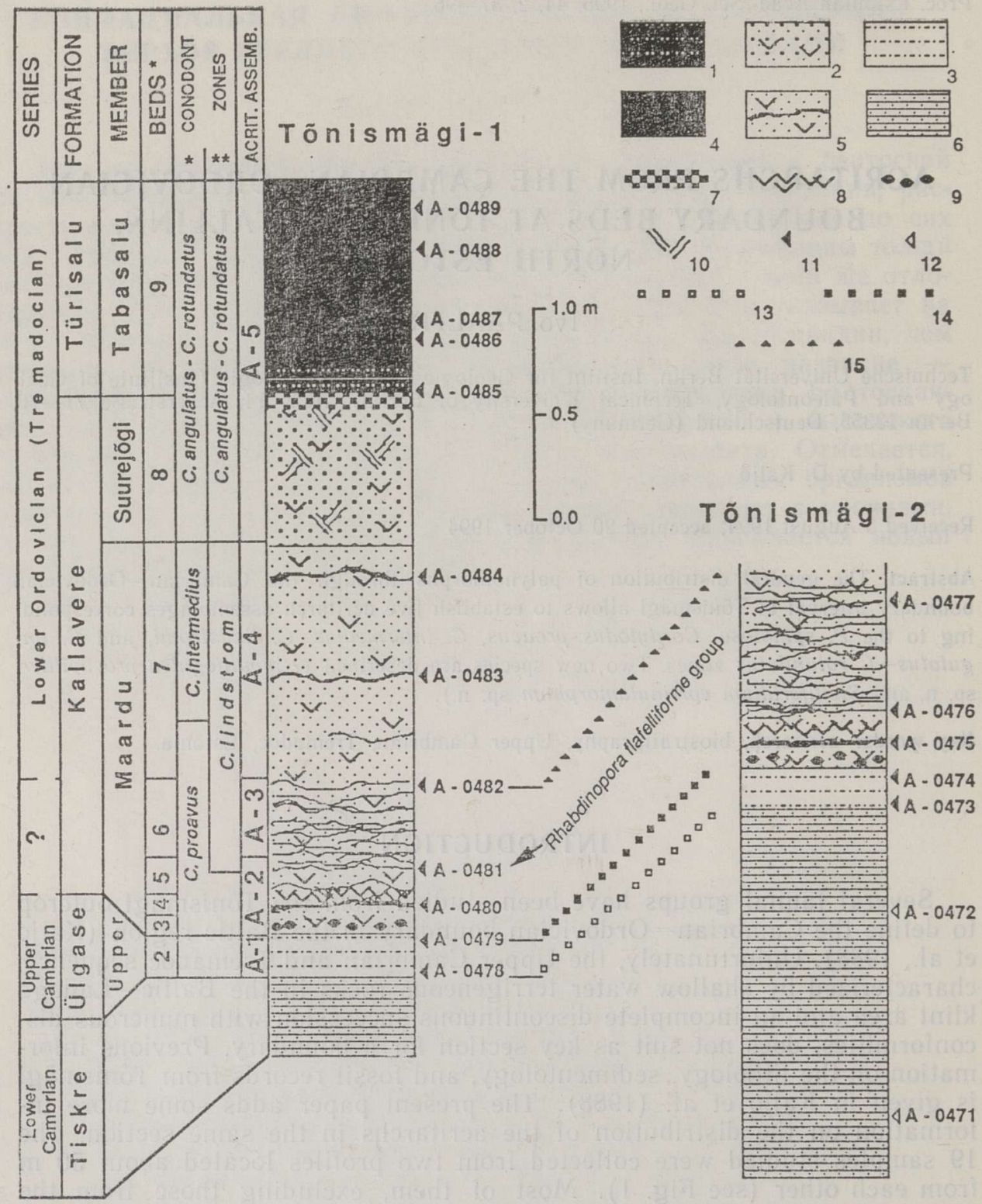

Fig. 1. The geological succession through the Cambrian--Ordovician boundary interval at Tõnismägi.

1 thin laminated organic-rich argillites; 2 coarse-grain sandstone with detritus; 3 siltstone; 4 compact organic-rich argillites; 5 sandstone with interbeds of organic-rich argillites and detritus; 6 intercalation of silt- and claystones; 7 pyrite-rich horizon; 8 "oboluscoquina"; 9 basal conglomerate; 10 cross-bedding; 11 sample with acritarchs; 12 sample without acritarchs; 13 the upper boundary of the Tiskre Formation; 14 the upper boundary of the Ulgase Formation; 15 the approximate lower boundary of Bed 7 ; * subdivision by Kaljo et al., 1988; ** subdivision by Norford, 1991.

Fig. 2. The distribution of the acritarchs through the Cambrian-Ordovician boundary interval in the Tõnismägi section. 


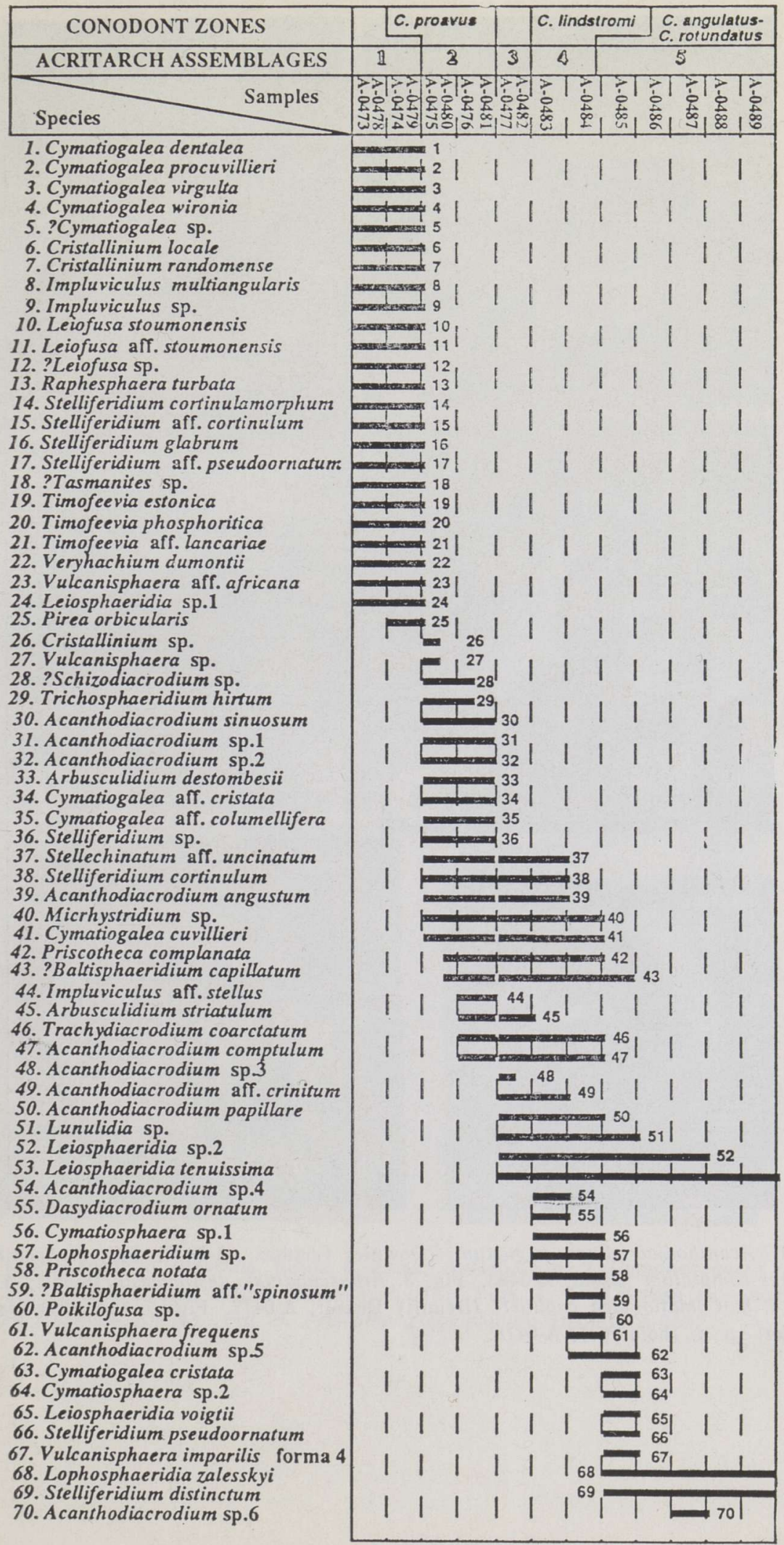




\section{PLATE I}
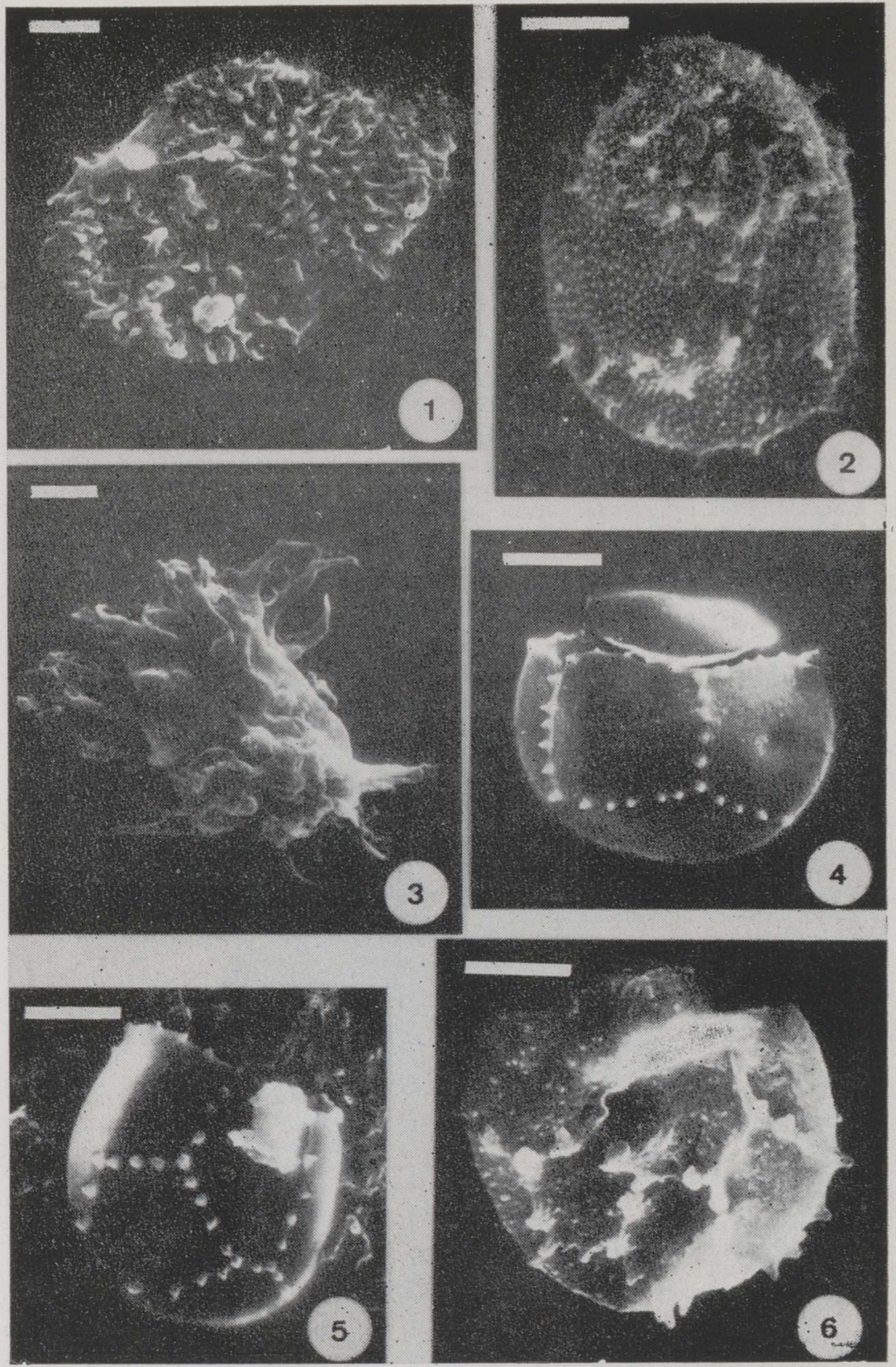

Fig. 1. Acanthodiacrodium angustum (Downie) Combaz; A-0477. Fig. 2. Acanthodiacrodium comptulum Rasul; A-0483. Fig. 3. Arbusculidium destombesii Deunff; A-0480. Figs. 4, 5. Cymatiogalea cuvillieri (Deunff) Deunff; A-0477. Fig. 6. Cymatiogalea procuvillieri sp. n. (holotype); A-0478. 

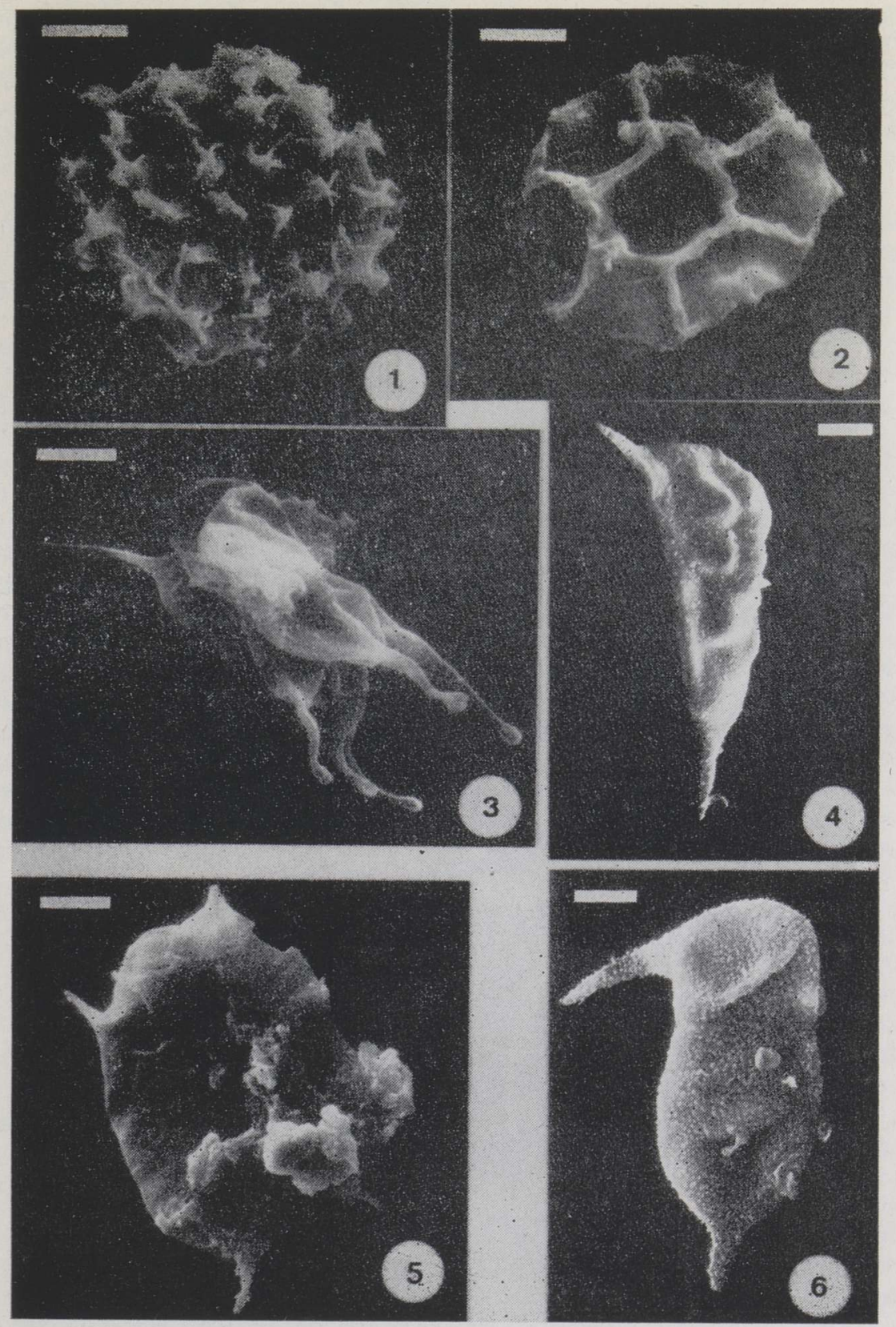

Fig. 1. Vulcanisphaera imparilis forma 4 Rasul; A-0485. Fig. 2. Cymatiosphaera sp.; A-0485. Fig. 3. Priscotheca notata Volkova; A-0483. Figs. 4, 6. ?Leiofusa sp.; Valkla, Olgase Fm., sample A-0343. Fig. 5. Priscotheca complanata Deunff; A-0481. 

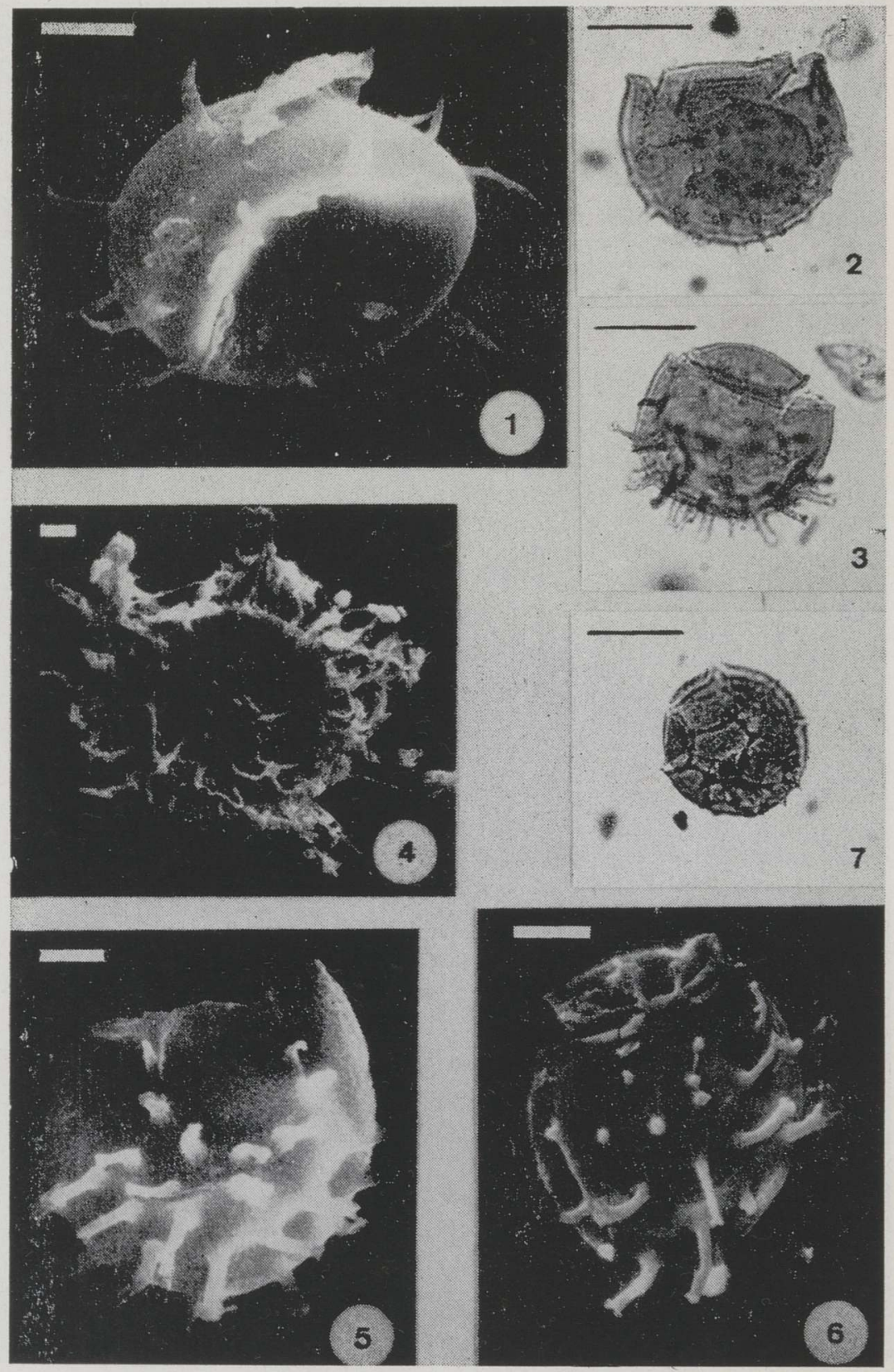

Fig. 1. ?Baltisphaeridium aff. "spinosum" Rasul; A-0483. Figs. 2, 3, 5. Stelliferidium cortinulamorphum sp. n. (holotype); A-0478. Fig. 4. Trichosphaeridium hirtum Timofeev; A-0481. Fig. 6. Stelliferidium cortinulum (Deunif) Deunff et al.; A-0477. Fig. 7. Cymatiogalea procuvillieri sp. n.; A-0478. 
The oldest microflora (A1), which contains typical Upper Cambrian acritarchs (Figs. 1, 2), comes from the Ulgase Formation at Tõnismägi (samples A-0473, A-0474, A-0478, A-0479). The same assemblage has been studied from different sections in North Estonia. At first it was considered to be an equivalent of the Tremadoc (Янкаускас \& Пашкявичене, 1972; Аристова, 1976), but later reinterpreted as a typical late Cambrian microflora (Mens et al., 1989; Mens et al., 1993; Волкова, 1982, 1990; Волкова \& Менс, 1988). Unfortunately, the Ulgase Formation is characterized by few fossil groups, only phosphatic inarticulate brachiopods Ungula inornata (Mickwitz) and Lingulella sp. were observed in the Tonnismägi locality (Kaljo et al., 1988). The former is considered to be a type species of Ungula inornata/Angulotreta postapicalis brachiopod Zone in the Baltic-Ladoga klint area (Puura \& Holmer, 1993; Попов et al., 1989) corresponding to the lowermost part of the Upper Cambrian (approximately $A$. pisiformis-P. spinulosa trilobite zones). On the basis of previous acritarch records, the Ulgase Formation was correlated roughly with Olenus and P. spinulosa zones (Mens et al., 1989; Волкова, 1982). However, this silty lithounit seems to have deposited for a relatively short time limited with the $P$. spinulosa Zone. I would like to draw attention to some other arguments confirming this conclusion.

First, assemblage A-1 contains a peculiar acritarch determined here as ?Leiofusa sp. (Pl. II, figs. 4,6). The same species was first described and illustrated by Potter (unpublished $\mathrm{Ph}$. D. Thesis, 1974) as short-ranging Leiofusa scalenabullata sp. $\mathrm{n}$. from the P. spinulosa Zone in Wales. In addition to Britain, a similar species is also found in Newfoundland where it is related to the lower and middle parts of the $P$. spinulosa Zone (Dr. Parsons, pers. comm.). The short-ranging ?Leiofusa sp. should be a good index acritarch for determining the $P$. spinulosa Zone in the East-European Platform as well as Britain and Newfoundland.

Secondly, the Upper Cambrian succession in Scandinavia indicates that the upper part of the Olenus Zone is usually missing except in Scania. The new transgression corresponding to the $P$. spinulosa Zone is registered elsewhere in Scandinavia, even in the Oslo region (see Martinsson, 1974, fig. 5). It is unlikely that the Baltic-Ladoga klint area, where the Upper Cambrian sequence is represented by terrigenous rocks typical of the shallow water conditions, was an area of sedimentation during the Olenus time, whereas at the same time a break is documented everywhere in Scandinavia. Probably, the Ulgase Formation was formed during the transgression recorded elsewhere in Scandinavia (Martinsson, 1974) and corresponds to the $P$. spinulosa Zone.

The lowermost part of the Maardu Member (= Beds 3-5) has been a subject of discussions for a couple of years. Bed 5 was previously correlated with the $C$. proavus Zone (Kaljo et al., 1988), but later reinterpreted by Norford (1991) and correlated with the base of the $C$. lindstromi Zone. Two samples, A-0480 and A-0475 collected from the argillite layer between the basal conglomerate and "obolus-coquina" (Fig. 1), contained Acanthodiacrodium angustum (Downie) Combaz, A. sinuosum Rasul, Acanthodiacrodium sp. 1, Acanthodiacrodium sp. 2, Arbusculidium destombesii Deunff, ?Baltisphaeridium capillatum Jardine et al., Cristallinium sp., Cymatiogalea cuvillieri (Deunff) Deunff, Cymatiogalea aff. columellifera (Deunff) Deunff, Cymatiogalea aff. cristata (Downie) Rauscher, Micrhystridium sp., Priscotheca complanata Deunff, Stelliferidium cortinulum (Deunff) Deunff, Gorka \& Rauscher, Stelliferidium sp., Trichosphaeridium hirtum Timofeev, Vulcanisphaera sp. Two samples (A-0481 and A-0476), collected some centimetres above the "obolus-coquina" bed (= Bed 5), yielded all the above-listed species (except Cristallinium sp. and Vulcanisphaera sp.), additionally also Acanthodiacrodium comptulum 
Rasul, Arbusculidium striatulum Volkova, and Impluviculus aff. stellus Rasul. The occurrence of graptolites from the Rhabdinopora flabelliformis group and of an element of Iapetognathus preaengensis on the same level (= Bed 5) adds confusion into the interpretation of this acritarch assemblage. The reason is that the first appearance of Rhabdinopora-type graptolites is regarded as a significant bioevent defining the lower boundary of the Tremadoc. This event was nearly contemporaneous with the appearance of $C$. lindstromi. This concept has found proof in several successions (Erdtmann, 1988; Fortey et al., 1991; Landing, 1993) and the earliest occurrence of Rhabdinopora-type graptolites in Estonia is considered to be questionable (Norford, 1991). One thing seems to be clear: A-2 from the base of the Maardu Member is older than A-4 distinguished from the upper part of the same unit (Figs. 1,2). The general distribution of acritarchs within the Maardu Member indicates one or two disconformities inside Bed 6 or at the base of Bed 7 at Tõnismägi.

A-2 contains several taxa, like $A$. angustum, $A$. comptulum, $A$. destombesii, and $A$. striatulum, which should be important from the biostratigraphic point of view. Up to now the last species has been recorded only in Estonia (Волкова, 1988) and it is probably endemic. A. angustum was proposed by Volkova (Волкова, 1990) to define the base of the Tremadoc (sensu C. proavus). This proposal was later discussed and criticized by Martin (1993). However, the results of several outcrop studies in Estonia (Волкова, 1989; Волкова \& Менс, 1988) confirm that the earliest specimens of $A$. angustum are established within the $C$. proavus Zone and its appearance may have been coeval with that of the index conodont or even earlier.

Probably, the earliest $A$. destombesii was recorded by Welsch (1986) from the lower part of the Berlogaissa Formation, which shows a typical acritarch community of the Peltura/Acerocare zones, and by Volkova (Волкова, 1990) from the same level in the Baltic area and in the Moscow Basin. In eastern Newfoundland the first $A$. destombesii were documented from the bottom of the Clarenville Formation (Martin \& Dean, 1981). This level is considered to be a critical one and correspond to the Acerocare Zone. The same species occurs, for instance in Marocco, in the base (= acritarch zone 1) of the Fezouata Formation (Elaouad-Debbaj, 1988). This portion of the formation (NB! with some graptolites determined as Dictyonema sp.) has been interpreted as the equivalent of the Dictyonema flabelliforme and Transitional Beds in Britain. The distribution of acritarchs through the Fezouata Formation indicates that the earliest acritarch assemblage comparable with acritarchs of the Dictyonema flabelliforme Beds in Britain (Rasul, 1979; Downie, 1984) could be assemblages 3 or 4 sensu Elaouad-Debbaj (1988) and in this case the lowermost part of the formation is older than considered earlier.

Unfortunately, not many successions proceeding through the Cambrian -Ordovician boundary interval have been studied in detail on acritarchs and other fossils. An exception is the Digermul section in the northern part of the East-European Platform where the first graptolites are documented in the lower part of the Berlogaissa Formation within acritarch biozone A-5 (Welsch, 1986). The Tremadoc age of assemblage A-5 was opposed and criticized by Volkova (Волкова, 1993). Its comparison with the material from the other parts of the East-European Platform shows quite clearly the late Cambrian age. With regard to the zonation proposed by Volkova (Волкова, 1990), the lowermost part of the Berlogaissa Formation (at least profile $1 \mathrm{a}-\mathrm{d}$ in Diegermul) is correlative with Peltura and/or Acerocare zones. However, the first Rhabdinopora are documented in the middle part of Be-1 (profile $2 \mathrm{a}-\mathrm{c}$ ) above the acritarch-bearing beds, whereas inside $\mathrm{Be}-1$ at least two levels with ripple 
marks (Welsch, 1986) are recorded. These may be indicative of disconformities. The middle (Be-2) and upper (Be-3) parts of the Berlogaissa Formation are characterized by a relatively low diversity of the acritarch assemblage without any good index taxa. $C$. cristata, chosen by Welsch to define assemblage A-6, has similar forms already in the upper Cambrian rocks and its biostratigraphic value is rather questionable. Consequently, A-6 from the Berlogaissa Formation seems to be older than considered by Welsch (1986).

A-3 is established about $0.6 \mathrm{~m}$ above the base of the Maardu Member (= Bed 6). This part of the section, which is barren of conodonts, yields acritarchs represented in A-2 and some new taxa (Acanthodiacrodium papillare Timofeev, Leiosphaeridia tenuissima Eisenack, and Lunulidia sp.). Over $90 \%$ of acritarchs derived from samples A-0482 and A-0477 belong to L. tenuissima and Leiosphaeridia sp. The bloom of the leiosphaeriids is well known and typical for instance of the Türisalu Formation. However, the acanthomorphic and galeat acritarchs accompanying L. tenuissima in A-3 are quite distinctive from those in the Türisalu Formation (Fig. 2). The precise correlation of Bed 6 remains open because assemblage A-3 has an "intermediate face" between assemblages A-2 and A-4. Its correlation with the $C$. intermedius Zone is not excluded.

A-4 comes from the upper part of the Maardu Member and is characterized by several new species (Fig. 2). Kaljo et al. (1988) concluded that Bed 7 corresponds to the $C$. intermedius Zone. Norford (1991) and Landing (1993) reinterpreted previous fossil evidences and assigned this part of the section to the $C$. lindstromi Zone.

Several acritarch species represented in A-4 should be good index taxa for the determination of the $C$. lindstromi Zone and maybe also the Tremadoc boundary. ?Baltisphaeridium aff. "spinosum" Rasul, Dasydiacrodium ornatum Combaz, Cymatiosphaera sp. 1, and Priscotheca notata Volkova, observed in the Tonnismägi section, have good correlation with C. lindstromi. Also some other taxa not represented at Tonnismägi but documented in other localities (Orasoja and Lamoshka sections, unpublished data of I. Paalits) co-occur with $C$. lindstromi. These are Acanthodiacrodium ubuii Martin and the Vulcanisphaera britannica Rasul-V. imparalis Rasul group. In Shropshire (England) several abovementioned species are first recorded in the Dictyonema flabelliforme Beds corresponding to the $C$. lindstromi Zone (Rasul, 1979). The assemblage A-4 has the best correlation and is comparable with acritarchs determined from the Dictyonema flabelliforme and Transitional Beds in Britain (Rasul, 1979; Downie, 1984) and with the Fezouata Formation (=acritarch zones 3 and 4) in Marocco (Elaouad-Debbaj, 1988).

The organic-rich argillites of the Türisalu Formation (Bed 9) corresponding to the $C$. angulatus - C. rotundatus Zone (Kaljo et al., 1988) contain low-diversity microflora (A-5) with the dominance of L. tenuissima and Lophosphaeridium zalesskyi (Naumova) Umnova accompanied by very rare acanthomorphic and galeat acritarchs (Acanthodiacrodium sp. 5 , Acanthodiacrodium sp. 6, Cymatiogalea cristata, Cymatiosphaera sp. 2, Leiosphaeridia voigti Eisenack, Stelliferidium pseudoornatum Pittau, S. distinctum (Rasul), and Vulcanisphaera imparilis forma 4). A similar palynoflora appears to be typical of the deposits of the $C$. angulatus Zone in the East-European Platform (Eisenack, 1958; Tongiorgi \& Ribecai, 1990; Умнова \& Фандерфлит, 1971; Умнова, 1975). 


\section{SYSTEMATIC DESCRIPTION}

Abbreviations: Dv-diameter of vesicle; Lp-total length of process; Lfplength of furcated part of process; Bp-basal breadth of process; Dpfdiameter of polygonal field; Dop-diameter of operculum; $\mathrm{Np}$-number of processes.

\section{ALGAE INCERTAE SEDIS}

\section{Group ACRITARCHA Evitt, 1963}

Genus Cymatiogalea Deunff, 1961, emend. Deunff, 1964, emend. Deunff, Gorka et Rauscher, 1974

?Cymatiogalea procuvillieri sp. $\mathrm{n}$.

Pl. I, fig. 6, pl. III, fig. 7

1990 Cymatiogalea aff. C. cuvillieri (Deunff) Deunff, Gorka et Rauscher: Волкова, pl. 8, fig. 5 .

1992 Cymatiogalea sp. 1: Paalits, Pl. I, fig. 3.

Holotype: P1. I, fig. 6.

Stratum typicum: Ulgase Formation, Upper Cambrian.

Locus typicus: Tõnismägi section in Tallinn, North Estonia.

Material: more than 20 specimens.

Diagnosis: Vesicle originally globular. The processes are homomorphic and placed regularly dividing the vesicle into polygonal fields. The processes are small, solid, nonfurcated with acuminated or blunted tips. These have a curved contact with the vesicle and are proximally sometimes ornamented with a ray-like structure. The processes can be connected with each other with a fold.

The configuration of the fields is usually pentagonal. The hexagonal and quadrangular types of fields are rare. The edge of the fields is bordered by three processes. The formula of the tabulation is $1: 6: 6: 1$, $1: 5: 6: 1$, or $1: 5: 2$. The surface on the vesicle is smooth or rugulated.

The excystment is represented by a pylom-like structure formed by separation of the pseudotabulae.

Dimensions: (10 specimens) Dv: $16.5-28.0 \quad$ (20.1) $\mu \mathrm{m} ; \quad \mathrm{Lp}: 1.5-3.0$ (2.0) $\mu \mathrm{m}$; Dpf: $6.0-8.5$ (7.5) $\mu \mathrm{m}$; Dop: 8.0-11.5 (9.5) $\mu \mathrm{m}$.

Comparison: ?C. procuvillieri sp. n. differs from C. cuvillieri (Pl. I, figs. $4,5)$ in the number of the processes bordering the edge of the polygonal fields and in the morphology of processes. The holotype of $C$. cuvillieri illustrated by Deunff (1961) has four processes on an edge and it bears a well-developed typical macropylom, which is absent in ?C. procuvillieri sp. $\mathrm{n}$.

Remarks: ?C. procuvillieri sp. $\mathrm{n}$. has an excystment mode nontypical but quite commonly represented in several late Cambrian acritarchs, for instance Raphesphaera and Cristallinium. It is characterized by an unclearly developed pylom-like structure without a distinct operculum. The rupture-like opening of ?C. procuvillieri sp. $\mathrm{n}$. follows the edges of the pseudotabulae (Pl. I, fig. 6). In the extreme case the opening rupture can occupy more than one pseudotabula (see also Волкова, 1990, pl. 8, fig. 5). It is supposed here that acritarchs of ?C. procuvillieri sp. n. type represent an ancestor lineage of the galeate acritarchs with an archaic excystment mode. 
Occurrence: Ulgase and Tsitre formations, corresponding to the Parabolina spinulosa and Leptoplastus zones, Upper Cambrian, North Estonia (Paalits, 1992; Волкова, 1990).

\section{Genus Stelliferidium Deunff, Gorka et Rauscher, 1974}

Stelliferidium cortinulamorphum sp. $\mathrm{n}$.

Pl. III, figs. 2,3 , and 5

1990 Stelliferidium aff. S. cortinulum (Deunff) Deunff, Gorka et Rauscher: Волкова, pl. 2, figs. 17 and 19.

1991 ?Stelliferidium sp. cf. S. cortinulum (Deunff) Deunff, Gorka et Rauscher: Di Milia, pl. 2, fig. 12.

1992 Stelliferidium sp.: Paalits, Pl. I, fig. 7.

Holotype: Pl. III, fig. 5.

Stratum typicum: Ulgase Formation, Upper Cambrian.

Locus typicus: Tõnismägi section in Tallinn, Estonia.

Material: over 200 specimens.

Diagnosis: Vesicle originally globular, with macropylom and covered with processes. These are heteromorphic and located irregularly on the antapex and regularly on the apex. The interval between processes varies from 2 to $5 \mu \mathrm{m}$. The distal parts of the processes are furcated to the first or second order. The proximal parts of the processes are widened, they have curved contact with vesicle and are weakly ornamented with ray-like folds. The interior of processes is solid or hollow (represented by single trabeculates) without free communication into the vesicle cavity. The antapex is totally covered with processes. On the apex some processes are located regularly in rows. Usually four or five rows are formed in a tabulation-like order. The row consists of two or three processes.

The surface on the vesicle and on the operculum is uniform, rugulated. The configuration of the pylom and operculum is rounded, subrounded, or subpolygonal. The pylom is simple without or with a collar and decorated with knob-like nonfurcated processes.

Dimensions: Dv: $25.0-37.5$ (31.6) $\mu \mathrm{m}$; Dop: $5.0-22.0$ (17.5) $\mu \mathrm{m}$; Lp: $3.5-$ 8.5 (6.5) $\mu \mathrm{m}$; Bp: $1.7-2.5$ (2.3) $\mu \mathrm{m}$; Lfp: $0.5-4.5$ (1.6) $\mu \mathrm{m}$; Np: $19-58$ (37).

Comparison: S. cortinulum appears to be one of the most often cited acritarch species from the Upper Cambrian-Tremadocian rocks elsewhere in the world. However, its diagnosis seems to be unclearly defined. Typical S. cortinulamorphum sp. n. differs from S. cortinulum in the location of the processes, which are arranged irregularly on the anapex and placed regularly on the apex.

$S$. cortinulamorphum $\mathrm{sp}$. n. may be an intermediate form between stelliferiids and cymatiogaleas because of common elements in the morphology of both genera. For instance, the ray-like structure on the bases of processes and their irregular location on the anapex pole is characteristic of stelliferiids and weakly developed pseudotabulation on the apex is a typical morphological element of cymatiogaleas.

Occurrence: Very common in the Ulgase and Tsitre formations, Upper Cambrian, $P$. spinulosa-Leptoplastus zones, North Estonia; Solanas Sandstone Formation, Upper Cambrian, Central Sardinia, Italy (Di Milia, 1991). 
Financial support was provided by the Deutsche Forschungsgemeinschaft, project ER-96/13-1. I am grateful to R. Brocke, B.-D. Erdtmann, O. Fatka, T. Heuse, D. Kaljo, K. Mens, A. Noor, and U. Moldov for their comments and for revising the manuscript.

\section{REFERENCES}

Deunff, J. 1961. Un microplancton à hystrichosphéres dans le Trémadoc du Sahara. Revue de Micropaléontologie, 4, 1, 37-52.

Di Milia, A. 1991. Upper Cambrian acritarchs from the Solanas Sandstone Formation, Central Sardinia, Italy. - Boll. Soc. Paleontol. Ital., 30, 2, 127-152.

Downie, C. 1984. Acritarchs in British stratigraphy. - Geol. Soc. London, Special Report $17,1-26$.

Eisenack, A. 1958. Mikrofossilien aus dem Ordovizium des Baltikums. 1. Markasitschichte, Dictyonema-Schiefer, Glaukonitsand, Glaukonitkalk. - Senck. leth., 39, 5/6, $389-405$.

Elaouad-Debbaj, Z. 1988. Acritarches et chitinozoaires du Trémadoc de l'Anti-Atlas central (Maroc). - Revue de Micropaléontologie, 31, 2, 85-128.

Erdtmann, B.-D. 1988. The earliest Ordovician nematophorid graptolites: Taxonomy and correlation. - Geological Magazine, 125, 4, 327-348.

Fortey, R. A., Bassett, M. G., Harper, D. A. T., Hughes, R. A., Ingham, J. K., Molyneux, S. G., Owen, A. W., Owens, R. M., Rushton, A. W. A. \& Sheldon, P. R. 1991. Progress and problems in the selection of stratotypes for the bases of series in the Ordovician System of the historical type area in the U. K. - In: Barnes, C. R. and Williams, S. H. (eds.). Advances in Ordovician Geology. Geol. Surv. Canada, Paper 90-9, 5-25.

Kaljo, D., Heinsalu, H., Mens, K., Puura, I. \& Viira, V. 1988. Cambrian-Ordovician boundary beds at Tõnismägi, Tallinn, North Estonia. - Geological Magazine, $125,4,457-463$.

Landing, E. 1993. Cambrian-Ordovician boundary in the Taconic Allochthon, eastern New York, and its interregional correlation. - J. Paleont., 67, 1, 1-19.

Martin, F. 1993. Acritarchs: A review. - Biol. Rev., 68, 475-538.

Martin, F. \& Dean, W. T. 1981. Middle and Upper Cambrian and Lower Ordovician acritarchs from Random Island, eastern Newfoundland. - Geol. Surv. Canada, Bull. $343,1-43$.

Martinsson, A. 1974. The Cambrian of Norden. - In: Holland, C. H. (ed.). Cambrian of the British Isles, Norden and Spitsbergen. John Wiley \& Sons, London, 185-283.

Mens, K., Viira, V., Paalits, I. \& Puura, I. 1989. Cambrian-Ordovician boundary beds at Mäekalda, Tallinn, North Estonia. - Proc. Estonian SSR Acad. Sci. Geol., 38, 3, 101-111.

Mens, K., Viira, V., Paalits, I., \& Puura, I. 1993. Upper Cambrian biostratigraphy of Estonia. - Proc. Estonian Acad. Sci. Geol., 42, 4, 148-159.

Norford, B. S. 1991. The international working group on the Cambrian-Ordovician boundary: Report of progress. - In: Barnes, C. R. and Williams, S. H. (eds.). Advances in Ordovician Geology. Geol. Surv. Canada, Paper 90-9, 27-32.

Paalits, I. 1992. Upper Cambrian acritarchs from boring core M-72 of North Estonia. Proc. Estonian Acad. Sci. Geol., 41, 1, 29-37.

Puura, I. \& Holmer, L. 1993. Lingulate brachiopods from the Cambrian-Ordovician boundary beds in Sweden. - Geologiska Föreningens i Stockholm Förhandlingar, $115,3,215-237$.

Rasul, S. M. 1979. Acritarch zonation of the Tremadoc Series of the Shineton Shales, Wrekin, Shropshire, England. - Palỵnology, 3, 53-72, 
Tongiorgi, M. \& Ribecai, C. 1990. Late Cambrian and Tremadocian phytoplankton (acritarchs) communities from Oland (Sweden). - Boll. Soc. Paleontol. Ital., $29,1,77-88$.

Welsch, M. 1986. Die Acritarchen der Höheren Diegermul Gruppe, Mittelkambrium bis Tremadoc, Ost-Finnmark, Nord-Norwegen. - Palaeontographica, Abt. B, 201, $1-109$.

Аристова К. Е. 1976. Комплексы микрофитофоссилий нижнего и среднего ордовика эталонных разрезов Эстонии. - Тр. БНИГРИ, вып. 192, 11-20.

Волкова Н. А. 1982. О возрасте юльгазеской пачки на границе кембрия и ордовика в Эстонии. - Сов. геол., 9, 85-88.

Волкова Н. А. 1988. Новые виды акритарх из нижнего тремадока Эстонии. - In: Палинология в СССР. Наука, Новосибирск, 79-82.

Волкова Н. А. 1989. Акритархи верхней части пакерортского горизонта севера Эстонии и Ленинградской области. - In: Палеофлористика и стратиграфия фанерозоя. Москва, 4-16.

Волкова Н. А. 1990. Акритархи среднего и верхнего кембрия Восточно-Европейской платформы. Наука, Москва.

Волкова Н. А. 1993. Таксономический состав акритарх и климат в раннем тремадоке Балтийской фитопланктонной провинции. - Стратиграфия. Геологическая корреляция, $\mathbf{1}, 5,39-43$.

Волкова Н., Менс К. 1988. Распределение акритарх в пограничных слоях кембрия и ордовика разреза Сухкрумяги (Северная Эстония). - Изв. АН ЭССР. Геол., 37, 3, 97-102.

Попов Л. Е., Хазанович К. К., Боровко Н. Г., Сергеева С. П., Соболевская Р. Ф. 1989. Опорные разрезы и стратиграфия кембро-ордовикской фосфоритоносной оболовой толщи на северо-западе Русской платформы. Наука, Ленинград.

Умнова Н. И. 1975. Акритархи ордовика и силура Московской синеклизы и Прибалтики. Недра, Москва.

Умнова Н. И., Фандерфлит Е. К. 1971. Комплексы акритарх кембрийских и нижнеордовикских отложений запада и северо-запада Русской платформы. - In: Палинологические исследования в Белоруссии и других районах СССР. Наука и техника, Минск, 45-73.

Янкаускас Т., Пашкявичене Л. 1972. Микропалеонтологическая характеристика юльгазеской пачки тремадока Эстонии. - Изв. АН ЭССР. Хим. Геол., 21, 1, 92-93.

\title{
AKRITARHID KAMBRIUMI JA ORDOVIITSIUMI PIIRIKIHTIDEST TÕNISMÄE PALJANDIST TALLINNAS
}

\author{
Ivo PAALITS
}

Tõnismäe paljandist on võimalik välja eraldada vähemalt viis akritarhikompleksi, mis on korreleeritavad $P$. spinolosa, $C$. proavus'e, $C$. intermedius'e, $C$. lindstromi ja $C$. angulatus'e-C. rotundatus'e tsoonidega. Graptoliite sisaldava Maardu kihistiku basaalis (kihid 3-5) leidub akritarhe, mis on iseloomulikud $C$. proavus'e tsoonile. $C$. lindstromi tsoonile tüüpilised akritarhid on aga määratud Maardu kihistiku ülemisest osast (kiht 7). Süstemaatilises osas on kirjeldatud kaht uut liiki (?Cymatiogalea procuvillieri sp. n. ja Stelliferidium cortinulamorphum sp. n.). 


\section{АКРИТАРХИ ПОГРАНИЧНЫХ СЛОЕВ КЕМБРИЯ И ОРДОВИКА ИЗ РАЗРЕЗА ТЫНИСМЯГИ, ТАЛЛИНН}

\section{Иво ПААЛИТС}

В сводном разрезе пограничного интервала кембрия й ордовика, представленного отложениями юлгазеской, каллавереской и тюрисалуской свит, установлены пять комплексов акритарх. Нижний из них происходит из юлгазеской свиты, два следующих - из нижней части маардуской пачки каллавереской свиты, соответствующей конодонтовой зоне Cordylodus proavus, четвертый - из отложений зоны C. lindstromi и пятый - из отложений зоны C. angulatus-C. rotundatus.

Даны описания двух новых видов - ?Cymatiogalea procuvillieri . sp. n. и Stelliferidium cortinulamorphum sp. n. 